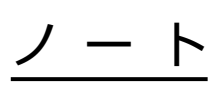

\title{
小児粉砕薬における医薬品含有量および損失の評価
}

\author{
湧井宣行 ${ }^{* 1,2}$ ，大久保哲生 ${ }^{1}$, 岩崎雄介 ${ }^{1}$ ，伊藤里恵 ${ }^{1}$, 小林 岳 $^{2}$, \\ 早川和宏 ${ }^{2}$,三井みゆき ${ }^{2}$, 矢野裕一 ${ }^{2}$, 斉藤貢一 ${ }^{1}$, 中澤裕之 ${ }^{1}$ \\ 星薬科大学薬品分析化学教室 ${ }^{1}$, 川崎市立川崎病院薬剂部 ${ }^{2}$

\section{Estimation of Infant Medicine Content and Drug Loss after Grinding Small Amount of Tablets}

\begin{abstract}
Nobuyuki Wakui ${ }^{* 1,2}$, Tetsuo Ookubo ${ }^{1}$, Yusuke Iwasaki ${ }^{1}$, Rie Ito ${ }^{1}$, Takeshi Kobayashi ${ }^{2}$, Kazuhiro Hayakawa ${ }^{2}$, Miyuki Mitsui ${ }^{2}$, Yuichi Yano ${ }^{2}$, Koichi Saito ${ }^{1}$ and Hiroyuki Nakazawa ${ }^{1}$

Department of Analytical Chemistry, Hoshi University ${ }^{1}$, Department of Pharmacy, Kawasaki Municipal Kawasaki Hospital ${ }^{2}$

[ Received July 22, 2010$]$

Accepted May 9, 2011

The pulverization of tablets for the preparation of pediatric medicines causes problems with respect to content uniformity and amount of the main ingredient. We compared these 2 factors in a pediatric medicine prepared by 2 methods: tablet grinding and tablet dilution. We also investigated causes of drug loss by means of high-performance liquid chromatography (HPLC).

Three pharmacists prepared cortril powder by each method. When the main ingredient content was calculated by quantitative analysis by means of HPLC, there was no significant difference between the 2 methods, and adhesion to the mortar and the package were considered to be major reasons for drug loss.

We also examined the effect of the amount of diluent on the loss of the main ingredient in the grinding process, finding that increasing the amount of diluent minimized the loss of the main ingredient content. When the amount of diluent per package was $1.5 \mathrm{~g}$, the main ingredient content was $90.8 \%(\mathrm{n}=3)$.

These results suggest that when dispensing small amounts of ground tablets, more attention should be paid to the amount of diluting agents than to the grinding technique.
\end{abstract}

Key words — infant medicine, drug-loss, pulverization of tablets, HPLC

\section{緒言}

近年, 簡易懸濁法の普及により医薬品の粉砕調剤は減 少傾向にある。簡易眯濁法は，錠剂 1 錠を $55^{\circ} \mathrm{C}$ のお湯 $20 \mathrm{~mL}$ に入れ 10 分間程度放置し, 䀣濁投与する方法 ${ }^{1)}$ あるが，微量調製が必要となる NICU等での小児薬用量 (1回辺り 0.1 錠等)では，均一薬液として小分け分配投与. できないため用いることができず，現在もなお粉砕調剤 で対応せざるを得ない現状がある。

従来, 粉砕調剂では力価や安定性の低下, 危篤な副作 用出現の可能性 ${ }^{2)}$, 重量損失等の問題点 ${ }^{3-6)}$ が指摘されて いる．特に小児の微量粉砕調剤においては，成人量に比 べ理論投与量に対しての薬剤損失の割合が大きくなり，

より精確な調製が要求される。少向けステロイド剤と

して頻用されるコートリル錠の投与量は $12 \sim 25 \mathrm{mg} / \mathrm{m}^{2} /$ 日
(新生児アジソン病補償量)である7)が，現在市販の錠剂 は $10 \mathrm{mg}$ 錠のみであり，小児投与に際しては微量な粉砕 調剤が度々必要となりより精確な粉砕調剤が求められる。

現在，薬局調剂で用いられている粉砕手法としては， 錠剂を粉砕し賦形剂を混合調剂する手法(粉砕法)，およ び錠剤を粉砕し賦形剂を加え，1gあたりの倍散を作成 後, 必要量を量り取りとる手法(倍散法)とがある。倍散 法は，主に院内製剤として散剤の予製を作成する際に用 いられるが，小児の粉砕調剤等での微量調製時でも均一 性の観点から粉砕法よりも有用であると考えられている。

粉砕調剤における薬剤損失の要因として, 乳鉢への付 着 $^{8)}$, 分包紙への付着 ${ }^{9}$ 等が報告されている. しかし, 微 量粉砕調剤時の手法別による主薬含有量, 薬剤損失の割 合を評価し, さらに主薬損失の回避方法について検討し

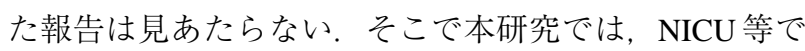
多用される微量粉砕調剂が必要とされる小児処方例をも 
とに，実際の調製方法に即して粉砕法および倍散法によ る粉砕調剤を行い, その際の主薬含有量や主薬変動(バ ラツキ)を高速液体クロマトフラフィー(HPLC)による主薬 の分析により検証し，さらに微量粉砕調剂時の精確な調 製方法について検討したので報告する.

\section{方法}

\section{1. 材料および試薬}

薬剤として，錠剤はコートリル錠(10)(日局ヒドロコル チゾン錠，ファイザー(株)), 賦形剤は日局乳糖(乳糖水和 物，シオエ製薬(株))を使用した。 ヒドロコルチゾン標準 品および内標準物質として用いたプレドニゾン標準品は 和光純薬工業株式会社製を使用した。エタノール， メ夕 ノールおよびアセトニトリルは和光純薬工業株式会社製 高速液体クロマトグラフィー用を使用した。精製水は日 本ミリポア株式会社製 Milli-Qの超純水装置で調製したも のを用いた。 ナイロンメンブランフィルター $(0.2 \mu \mathrm{m}$, $13 \mathrm{~mm})$ は日本ポール株式会社製を用いた。

\section{2. 標準溶液の調製}

標準溶液の調製にはエタノールを用い, ヒドロコルチ ゾン標準品 $1.0 \mathrm{mg} / \mathrm{mL}$ となるよう調製し, 希釈用保存溶 液とした。 さらに， $0.1 \sim 100 \mu \mathrm{g} / \mathrm{mL}$ の範囲となるよう水： メタノール $=50 ： 50(\mathrm{~V} / \mathrm{V}) て ゙$ 標準溶液を適宜希釈し, 測定 用試料とした。

\section{3. 使用機器}

錠剤の粉砕および薬剤の混合には，市販磁製乳鉢(直径

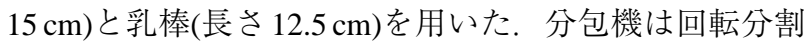
方式の全自動分包機((株)ユヤマ，YS-93WR-SY型)を使用 した，分包機に用いた分包紙は，株式会社ユヤマ製ポリ

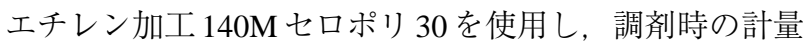
には, 電子上血天科((株)ユヤマ, LIBRA CS-620D, 感 量 $0.01 \mathrm{~g}$ )を用いた。

\section{4. コートリル粉砕散の調製}

微量調剂を施す粉砕処方例として, 実際の処方例の中 から、コートリル錠(10)を 1 回 $0.2 \mathrm{mg}, 1$ 日 2 回, 7 日分 (14包分)投与を用いた(図 1). 手法別のコートリル粉砕散 の調製では，3八の薬剤師がそれぞれ調剂分包し，一包 中の薬剤重量は，一般的な散剂調剂時の重量である一包 $0.2 \mathrm{~g}$ となるように賦形して行った。 また，同一人物内で の主薬のバラツキを評価するため, 一人の薬剤師が 3 回 粉砕法および倍散法により粉砕調剂を行った。

粉砕調剂を行うにあたり，微量粉砕調剂時の主薬含有 量を把握するため, 両手法とも実際の医療現場での臨床 に即した調製法により粉砕調剤を行った。粉砕法での調 製は，廃棄包数が少なくなるようコートリルの半錠(5 mg) を用い, 一包がそれぞれ $0.2 \mathrm{mg} / 0.2 \mathrm{~g}$ になるように，調

\section{Rp 1) コートリル蝊 (10 $\mathrm{mg} / \mathrm{T}$ ） 粉碎 分?

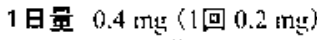 7 日分}

図 1. 微量粉砕調剂を要する小児処方例

製上の必要包数(25包)分の賦形剂を加え，乳鉢により混 合して分包した。また，倍散法による粉砕散の作成は， 作業の簡便性，合理性の観点から錠剤 1 錠を用いて行

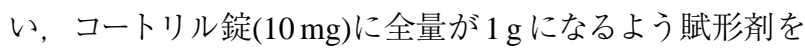
加え粉砕混合し，コートリル $10 \mathrm{mg} / \mathrm{g}$ の倍散を作成した 後，そこから処方上必要とされる包数分(14包分)を量り とり，一包が $0.2 \mathrm{~g}$ となるよう再賦形を行い混合したもの を分包した(図 2).

また, 手法別による粉砕散の主薬含有量の比較として, 粉砕する錠剤の主薬含量を同一(半剤 $5 \mathrm{mg}$ )に揃え，同一 調剂者が前述した手法ごとの手順で，粉砕調剤をそれぞ れ 5 回行った。

\section{5. 分割分包後のコートリル主薬含有量}

手法別に調剂分包したコートリル散を，HPLC分析に供 し，その均一性および個人別によるバラツキを検討した。 分割分包後のヒドロコルチゾン含有量は, 理論上含有さ れるべき量を $100 \%$ として，それぞれの主薬含有量を求 めた。

\section{6. 分包紙および乳鉢への付着}

微量調剤時における分包紙への薬剤付着の割合を検証 するため，手法別に分包後の医薬品を軽く振とうした 後，粉砕散を取り除いた空の分包紙を用いて，付着含量 を測定した。

また乳鉢への薬剤付着は，手法別によるコートリル粉 砕調剂後の乳鉢から主薬を抽出のうえ測定し，乳鉢での 主薬損失割合を求めた。

\section{7. 粉砕散中のヒドロコルチゾンの定量法}

1)装置および測定条件

実験に使用した高速液体クロマトグラフ／紫外吸光光 度検出器は SHISEIDO 社製 NANOSPACE 3001 システムを 用いた. HPLCカラムには Inertsil ODS-3(4.6×150 mm, $3 \mu \mathrm{m})$ カラムを用い, カラムオーブンは $40^{\circ} \mathrm{C}$ とした。移動 相は水：メタノール：アセトニトリル $=55 ： 30 ： 15(\mathrm{~V} / \mathrm{V} /$ V)により分離を行った。流速は $0.7 \mathrm{~mL} / \mathrm{min}$ で流し、サン プル注入量はオートサンプラーにより $20 \mu \mathrm{L}$ をインジェク ションした。内標準物質にはプレドニゾンを用いた。紫 外吸光光度検出器の検出波長は $254 \mathrm{~nm}$ で測定を行った。

また，上記記載の条件下での，粉砕散中ヒドロコルチ ゾンの検出限界は $0.1 \mu \mathrm{g} / \mathrm{mL}(\mathrm{S} / \mathrm{N}=10)$, 定量限界は $0.5 \mu \mathrm{g} /$ $\mathrm{mL}(\mathrm{S} / \mathrm{N}>10)$ であった。

2)測定試料の調製法 


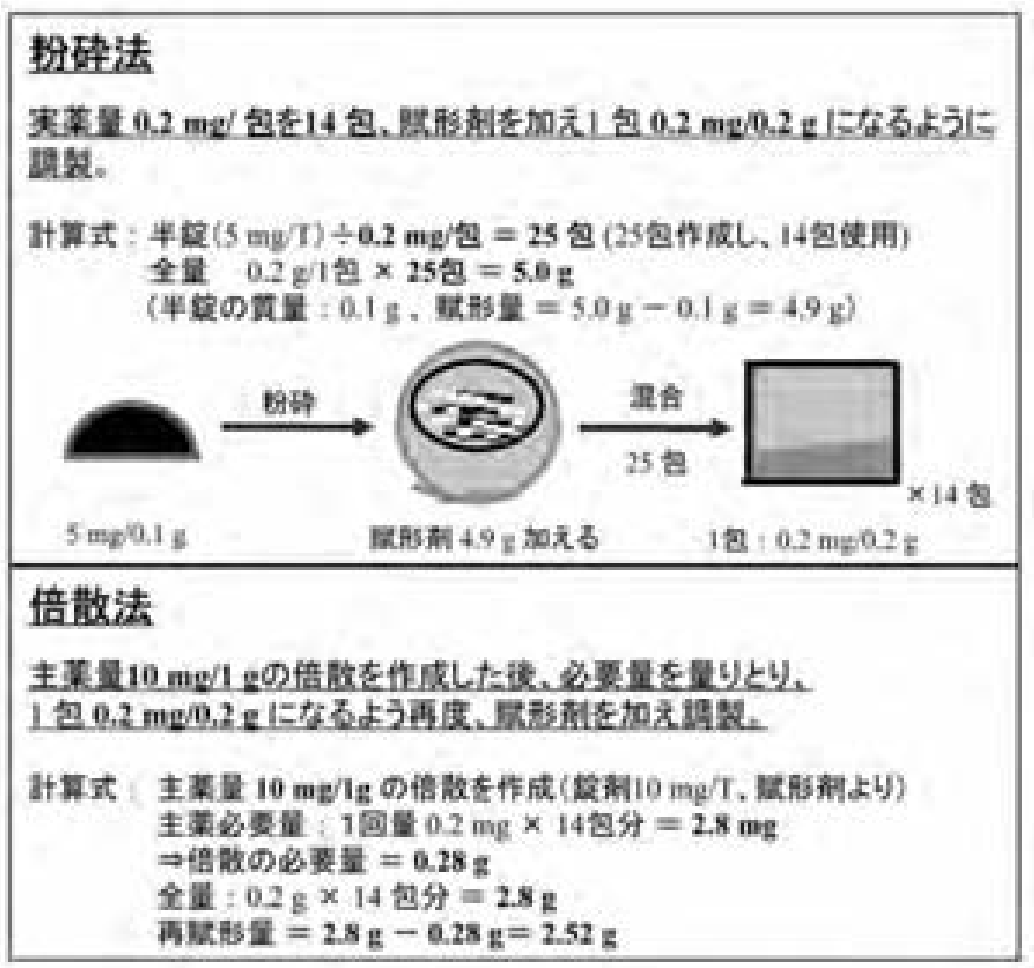

図 2. 手法別による粉砕散の調製方法

微量粉砕調剂を要する小览処方例を用いた際の粉砕法および倍散法に おける調製方法およびその際の計算式をそれぞれ示す.

\section{(1)粉砕散からの主薬の抽出}

粉砕散からのヒドロコルチゾンの抽出は，調剤分包後 の粉砕散に内標準物質を含む水/エタノール溶液を 0.2 $\mathrm{mL}$ 添加し，エタノールおよび精製水を各 $10 \mathrm{~mL}$ 加え，超 音波抽出を 10 分間行った後に，遠心分離(3000 rpm，5分 間)して得られた上清をナイロンメンブランフィルター $(0.2 \mu \mathrm{m})$ でろ過し，測定試料とした.

(2)乳鉢および分包紙からの主薬の抽出

乳鉢および分包紙からの主薬の抽出は, 調剤後の乳鉢 および空の分包紙に内標準溶液をそれぞれ $0.2 \mathrm{~mL}$ 加え， エタノール $10 \mathrm{~mL}$ により超音波抽出を 10 分行った後の溶 液に，水を $10 \mathrm{~mL}$ 加え振とうし，ナイロンメンブランフ イルター $(0.2 \mu \mathrm{m})$ でろ過したものを測定試料とした.

\section{8. 賦形剤の添加量による主薬含量への影響}

微量粉砕調剂時の主薬含量への影響として, 一包辺り の賦形剤量を増やして検討した。一包辺りの重量を $0.2 \mathrm{~g}$ から $1.5 \mathrm{~g}$ までの範囲となるよう賦形量を増やし，それに 伴う主薬含量の変化を分析評価した。

\section{9. 検定方法}

粉砕法及び倍散法による粉砕散作成は同一日に調製し た。また，粉砕法および倍散法での検体数は，それぞれ 3 人の薬剤師が各手法別に 1 回ずつ粉砕調剤を行い作成
した各 14 包すべてを測定し，それぞれ $\mathrm{n}=42$ として平均 值の差の検定を Unpaired t-testにより行った。

結果

\section{1. 測定条件の検討}

日本薬局方に記載されているコートリルの定量法は， 移動相に順相系溶媒のクロロホルムとメタノールを用い ている。しかし，現在クロロホルムは，工業的には広く 用いられているが，環境污染の観点から，その使用が厳 しく制限されつつある。このため，新たに逆相系溶媒に よる定量法を構築した。逆相系溶媒による分離定量は, 水：メタノール：アセトニトリル $=55: 30 ： 15(\mathrm{~V} / \mathrm{V} / \mathrm{V})$ の 3 種混合溶媒を用いた。この結果，移動相として一般的 に用いられる極性溶媒(水)と無極性溶媒(メ夕ノール，ア セトニトリル等)の 2 種の組み合せでは困難であった類似 骨格のステロイド剤の分離を可能とし，内標準物質およ び他の夾雑物質との良好な分離が可能となった(図 3).

\section{2. 添加回収試験}

検量線は，1.0から $100 \mu \mathrm{g} / \mathrm{mL}$ の濃度範囲において良好 な直線性 $(\mathrm{r}=0.999)$ を示した。また，賦形剂 $0.2 \mathrm{~g}$ 中に， ヒドロコルチゾンを $2 \mathrm{mg}$ および $0.2 \mathrm{mg}$ 添加し, 添加回収 試験を抽出処理後の最終測定濃度 $100 \mu \mathrm{g} / \mathrm{mL}$ および $10 \mu \mathrm{g} /$ 


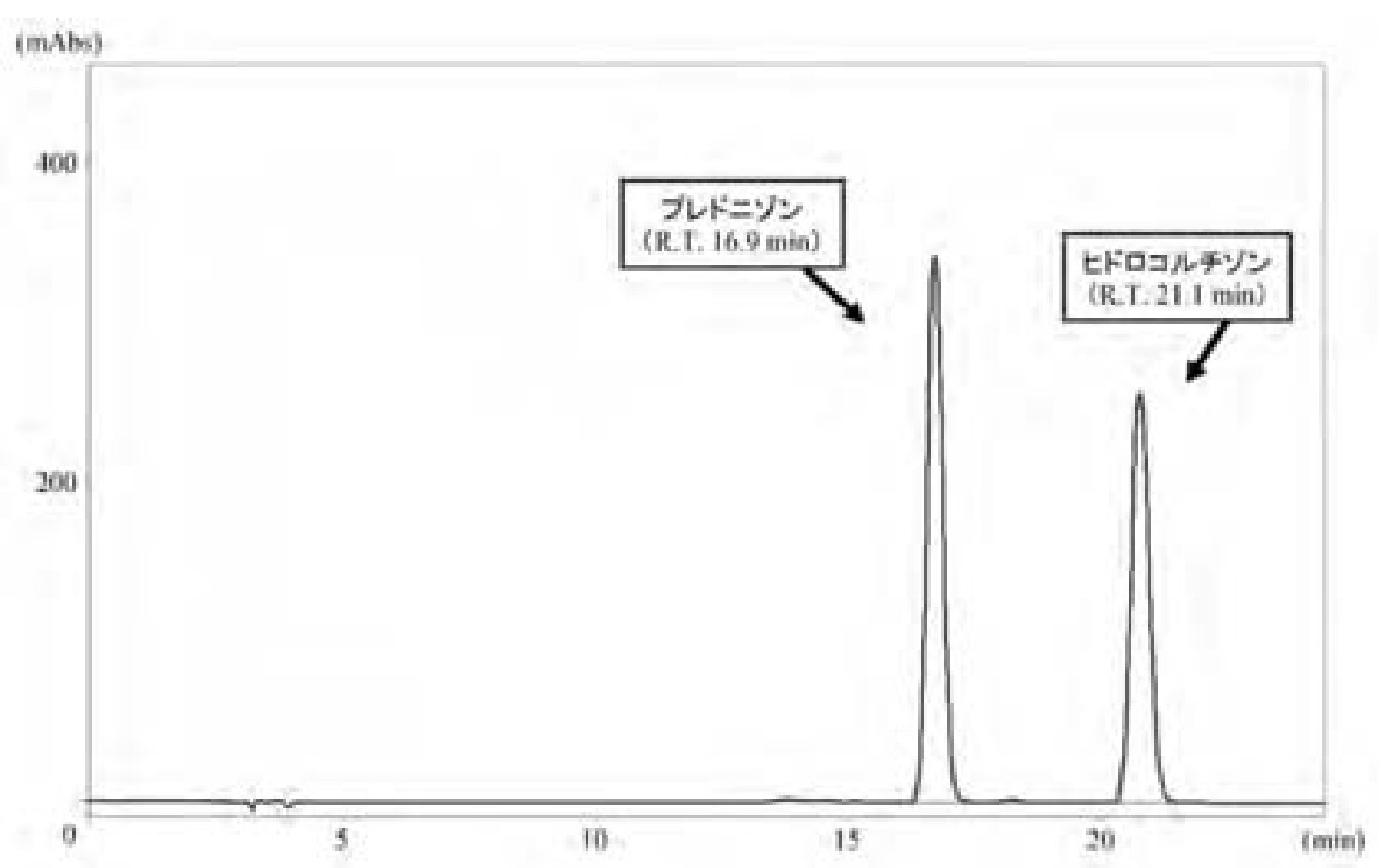

図 3. コートリル散(ヒドロコルチゾン：理論濃度 $10 \mu \mathrm{g} / \mathrm{mL})$ および 内標準物質(プレドニゾン : $5 \mu \mathrm{g} / \mathrm{mL})$ のクロマトグラム

$\mathrm{mL}$ で行ったところ，回収率(各 $\mathrm{n}=5)$ はそれぞれ 99.8\%(R. S.D.=2.2\%)および100.3\%(R.S.D.=7.5\%)であった。 また, 分析精度の確認としてコートリル 1 錠を用いてヒドロコ ロチゾンを抽出して，定量分析を行ったところ $(\mathrm{n}=5)$, 本分析法での錠剤からの主薬回収率は 102.1\%(R.S.D. = 2.1)であった。 これらの結果から，本分析法はコートリル 錠に含有される添加片等の影響を受けることなく，主薬 であるヒドロコルチゾンの高精度な定量分析が可能であっ た。また，乳鉢および薬包紙からの添加回収試験として， 同様にヒドロコルチゾンを $2 \mathrm{mg}$ および $0.2 \mathrm{mg}$ 添加して 行ったところ(各n=3), それぞれの最終測定濃度 $100 \mu \mathrm{g} /$ $\mathrm{mL}$ および $10 \mu \mathrm{g} / \mathrm{mL}$ において，乳鉢は 102.2\%(R.S.D.=4.1) および 99.5\%(R.S.D. = 4.6), 薬包紙では 100.7\%(R.S.D. = 3.8)および101.9\%(R.S.D.=4.3)であり，乳鉢，薬包紙にお いても，主薬であるヒドロコルチゾンの高精度な定量分 析が可能であった.

\section{3. コートリル粉砕散中の主薬定量}

構築した定量法を，3名の薬剤師 $(\mathrm{A})$ (C)が粉砕法お よび倍散法によって調剤した，粉砕散中のヒドロコルチ ゾンの分析に応用し，主薬含有量を算出した。この結 果，それぞれの薬剤師が 1 回の粉砕法および倍散法によ り調剂された同一分包内(全14包中)の薬剤師間での平均 主薬含有量およびそのバラツキは，それぞれ(A) $38.4 \%$ (0.0768 mg, R.S.D.=8.2), 40.9\%(0.0818 mg, R.S.D. = 14.1), (B) $48.9 \%(0.0978 \mathrm{mg}, \quad$ R.S.D. $=8.3), \quad 49.9 \%(0.0988$ mg, R.S.D. =9.9), (C)37.8\%(0.0756 mg, R.S.D. = 1.9),
43.4\%(0.0868 mg, R.S.D.=7.3)であった(表 1).

また，同一調剤者が，それぞれの手法別に 3 回粉砕調 剤を行った全 42 包を分析した平均主薬含有量は, それぞ れ粉砕法は 46.7\%(0.0934 mg, R.S.D = 15.9), 倍散法では 49.4\%(0.0988 mg, R.S.D.=18.4)であった。

さらに, 主薬含量を半錠 $(5 \mathrm{mg})$ に揃えて同一調剤者が 粉砕調剂を 5 回行った平均主薬含有量は, 粉砕法で 47.3\%(0.0946 mg, R.S.D. = 7.1), 倍散法では51.8\%(0.1036 mg, R.S.D.=26.4)であった.

\section{4. 医薬品損失の検討}

粉砕法および倍散法のそれぞれの乳鉢 $(\mathrm{n}=5)$ には, 理 論上の主薬含有率 $17.2 \%(0.0344 \mathrm{mg}$, R.S.D. $=9.5)$ および 17.8\%(0.0356 mg, R.S.D.=8.3)が付着していた. また，分 包紙 $(n=5) へ の$ 付着の検討結果では，粉砕法は $15.9 \%$ (0.0318 mg, R.S.D.=6.4), 倍散法では15.8\%(0.0316 mg, R.S.D. = 5.4)の值であった.

\section{5. 賦形剤の添加量による主薬含量への影響}

同一調剤者が 3 回粉砕法により粉砕調剤を行い, その 際に賦形量を多くして検討したところ，基準量 $0.2 \mathrm{~g}$ から $1.5 \mathrm{~g}$ に賦形量が増加するに従い, 一包辺りの主薬含有量 が増加し(各 $\mathrm{n}=3)$, 賦形量が $1.5 \mathrm{~g}$ での平均主薬含量は 90.8\%(0.1816 mg, R.S.D.=14.0)であった。 また各賦形量 辺りの分包後の重量平均は，それぞれ $0.189 \mathrm{~g}(-0.011 \mathrm{~g}$ : $0.2 \mathrm{~g}$ /包 $), 0.289 \mathrm{~g}(-0.011 \mathrm{~g}: 3 \mathrm{~g} /$ 包 $), 0.380 \mathrm{~g}(-0.02 \mathrm{~g}$ : $0.4 \mathrm{~g} /$ 包 $), 0.570 \mathrm{~g}(-0.03 \mathrm{~g}: 0.6 \mathrm{~g} /$ 包 $), 0.774 \mathrm{~g}(-0.026 \mathrm{~g}$ ： 
表 1. 調剤者および粉砕手法別による主薬含有量の検討

3 人の薬剂師がそれぞれ粉砕手法別にそれぞれ 1 回ずつ粉砕調剂を行い, 作成された各 14 包すべてを測定した際の平均主含有量および 3 人の平均值.

\begin{tabular}{ccccc}
\hline & \multicolumn{3}{c}{ 平均主薬含有量 } & i人口平均 \\
\cline { 2 - 5 } & $\mathrm{A}$ & $\mathrm{B}$ & $\mathrm{C}$ & (RSD) \\
\hline 粉砕 & 38.4 & 48.9 & 37.8 & $41.7 \%$ \\
& & & & $(14.3 \%)$ \\
\hline 倍散 & 40.0 & 49.9 & 43.4 & $44.8 \%$ \\
& & & & $(13.5 \%)$ \\
\hline
\end{tabular}

$0.8 \mathrm{~g} /$ 包 $), 0.993 \mathrm{~g}(-0.007 \mathrm{~g}: 1.0 \mathrm{~g} /$ 包 $), 1.219 \mathrm{~g}(-0.081 \mathrm{~g}$ : $1.3 \mathrm{~g} /$ 包), $1.418 \mathrm{~g}(-0.082 \mathrm{~g}: 1.5 \mathrm{~g} /$ 包)であった(図 4).

\section{考察}

構築した分析法を用いて, 粉砕医薬品中のコートリル の定量を行った。粉砕法および倍散法で調剤された， コートリルの散剤中の主薬含有率測定值では，倍散法に よるものがわずかながら高い含有率を示したが, Unpaired-t testにより有意差検定を行った結果，二方法間での有意差 は認められず，従来，倍散法は均一で精確な散剂作成方 法とされてきたが，本研究をモデルとした微量調剤時で は，どちらの手法を採用しても主薬含有量は変わらない 結果であった。 また，主薬含量のバラツキは倍散法の方 が大きく，この要因として，倍散法は使用する賦形剂量 が少ないため, 分包器での分包誤差および主薬損失が大 きく影響することが示唆された。

さらに，粉砕法および倍散法での主薬含有率がともに 低かったことから，調剤過程における医薬品損失の原因 を検討するため，手法別に調剂した後の乳鉢および分包 紙に着目し，それぞれでの主薬損失率を算出したところ， 手法に関係なく一定の損失割合で主薬損失に大きく関与 していた。

また，内服量，分包紙，乳鉢への付着の結果から，そ れぞれの主薬の割合を平均化し算出したところ，今回の ような微量なコートリル錠での粉砕調剤処方例では，1回 辺りの処方量に対して 40\%〜 50\%ぐらいしか投与されて おらず，少ない場合では，37\%しか投与されていないケー スも存在した。 これらから，主薬の損失要因として，お よそ30\%近くが乳鉢および分包紙への付着によるもので あり，また，同一薬剤師が粉砕調剤を行った場合でも， 主薬量のバラツキが大きい結果となり，薬剤師個々の手 技的問題とは別に，その他の損失要因(25\%近く)とし て, 分包器等への付着損失が大きく関与していることが 考えられた。

さらに，主薬損失の回避方法の検討では，分包器での
付着損失を考慮し, 通常, 分包器の掃除作業で行われ る，「乳糖の空まき」での薬剤吸着効果を応用し，賦形 する乳糖の量を多くして分包器での回収率増加を試みた 結果, 初期賦形量 $0.2 \mathrm{~g}$ から $1.5 \mathrm{~g}$ と増加するに従い, 主 薬量含量の精確性が増加し，賦形量が $1.5 \mathrm{~g}$ では，主薬 含量 $90.8 \%(n=3)$ となった(図 4). この結果から，賦形剂 の量を多くすることで，賦形剤への主薬吸着により，分 包器だけでなく, 乳鉢, 薬包紙での損失も防止できるこ とが示唆された。

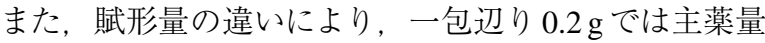
でおよそ 40\%，1.5gではおよそ $90 \%$ となり，賦形量の違 いにより主薬の投与量が 2 倍異なること示された。これ らのことから，賦形量の増加は精確な投与を可能とする が，反面，小児では内服量が多くなり過ぎてしまい，服 用が困難となることも想定され，個々の薬剤で最適な賦 形量を求める必要がある.

本研究をモデルとした微量な粉砕調剂では，従来，主 薬含量への実質的な配慮が余り検討されることなく，多 くの病院，薬局では画一的な賦形量 $(0.2 \mathrm{~g} /$ 包 $)$ で調剤され てきたが，今後は，単に服用上の飲みやすさからだけで なく，投与量の精確性を考慮した賦形量の設定を行うこ とが必要である。

\section{引用文献}

1) 倉田なおぬ，藤島一郎，“内服薬経管投与ハンドブック第 2 版 - 簡易懸濁法可能医薬品一覧”，じほう，東京，2006, pp.1一最終頁.

2) J.D. Cleary, P.C. Evans, A.H. Hikal, S.W. Chapman, Administration of crushed extended-release pentoxifylline tablets: bioavailability and adverse effects, Am. J. Health Syst. Pharm., 56, 1529-1534(1999).

3) 桑名由紀子, 平松弘子, 古市勝久, 住田克己, 調剤中錠剂 粉砕に伴う重量口ス, 病院薬学, 4, 16-19(1978).

4) 宮本昌二，鈴木勝，幸田幸直，調剤工程および服用時の薬 剂損失, 病院薬学, 25, 292-298 (1999).

5) 佐々木誠, 佐野雅俊, 田中靖子, 山本育由, カルベジロー 
(1)

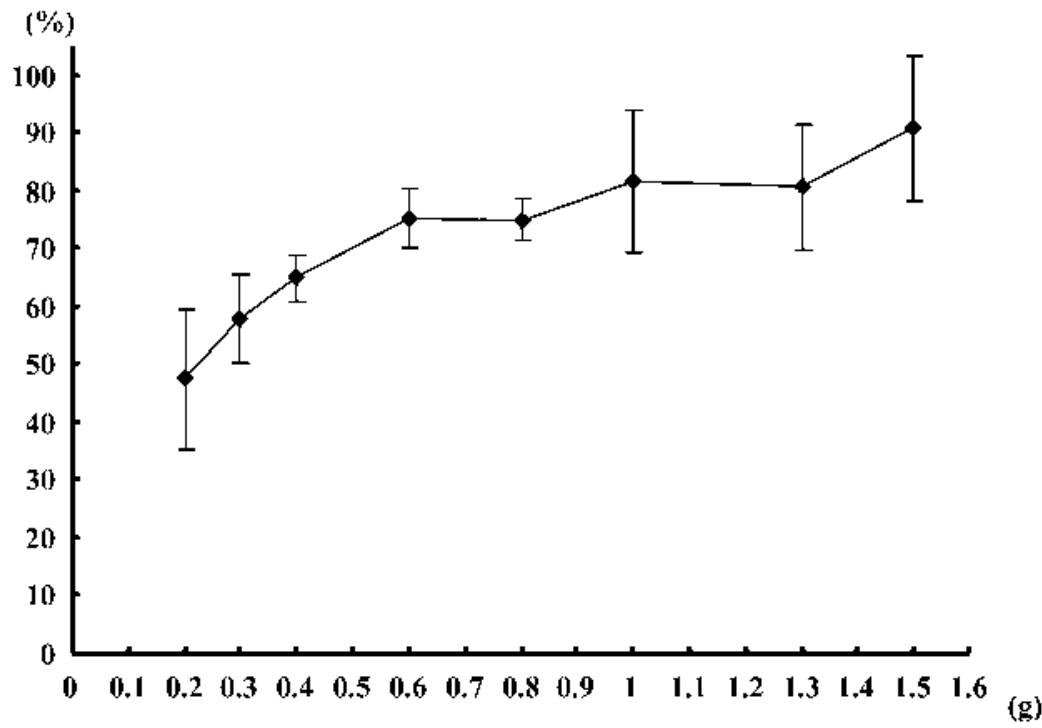

(2)

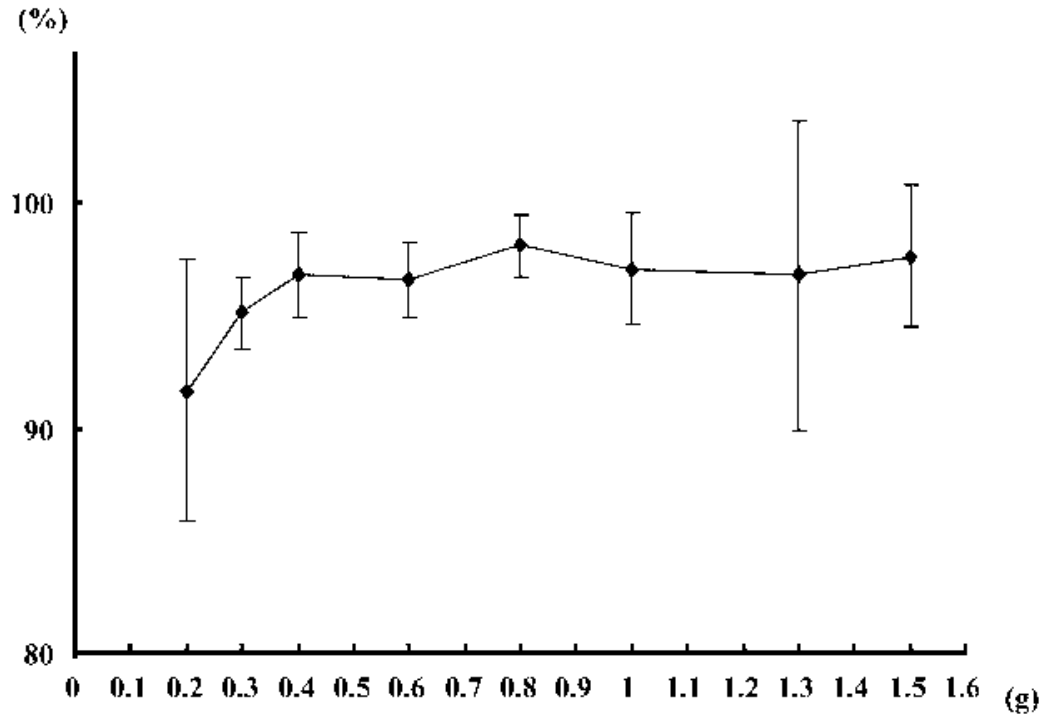

図 4. 賦形剤の量に対するヒドロコルチゾン含有量と分包後の重量

1 人の薬剤師が, 1 包辺りの重量を $0.2 \mathrm{~g}$ から $1.5 \mathrm{~g}$ までの範囲で賦形剤を加えて粉砕法で調剤 した際の(1)ヒドロコルチゾン含有量および(2)賦形量に対する分包後の重量.

ル錠の粉砕・管過および自動分包調剂による薬剤損失, 医療薬学, 32, 420-423(2006).

6) 村上美和子，田上直美，中村千鶴子，鸖田聡，岩奥玲子， 中野眞沉, 錠剤粉砕時の重量ロスの検討, 病院薬学, 17, 381-387 (1991).

7) 五十嵐隆, 渡辺博, 木津順子, “新 小览薬用量 改定第4 版”, 診断と治療社, 東京, 2006, pp.261-262.
8) 長廻貞雄, 石村明彦, 平野栄作, 岩本喜久生, 錠剂粉砕に よる $\beta$-メチルジゴキシン散剤の付着性, 病院薬学, 20, 466-473 (1994).

9) 佐々木誠, 佐野雅俊, 田中靖子, 山本育由, カルベジロー ル錠の粉砕・篩過および自動分包調剤による薬剂損失, 医療薬学, 32, 420-423(2006). 